\title{
Devitalisation of pathogens in stored pig slurry and potential risk related to its application to agricultural soil
}

\author{
Jan Venglovsky $^{1}$ (D) Nada Sasakova ${ }^{1} \cdot$ Gabriela Gregova $^{1} \cdot$ Ingrid Papajova $^{2}$. \\ Frantisek Toth $^{2} \cdot$ Tatiana Szaboova $^{1}$
}

Received: 20 November 2016 / Accepted: 23 October 2017 /Published online: 31 October 2017

(C) The Author(s) 2017. This article is an open access publication

\begin{abstract}
The study investigated the risks arising from application of pig slurry to soil in relation to viability of Salmonella typhimurium, Escherichia coli, total coliforms, faecal enterococci and eggs of Ascaris suum at different temperatures. Potential effect of changes in physico-chemical parameters, particularly dry matter (DM), pH and ammonia, were also investigated. Examination showed that $S$. typhimurium was devitalised after storage in the slurry for 115 days at $4{ }^{\circ} \mathrm{C}$ and after 90 days at 20 and $42{ }^{\circ} \mathrm{C}$. Devitalization of E. coli and faecal entrerococci required more than 115 at temperature of $4{ }^{\circ} \mathrm{C}$ and faecal enterococci were recovered from slurry after 115 days of storage even at temperature of $20^{\circ} \mathrm{C}$. Total coliforms survived for 115 days at all investigated temperatures. Complete devitalization of A. suum eggs was not achieved even after 115 days at $42{ }^{\circ} \mathrm{C}$. Our investigations indicated potential microbial and parasitic risk related to application of pig slurry to soil even after 115 days of storage.
\end{abstract}

Keywords Pig slurry $\cdot$ E. coli $\cdot$ Salmonella typhimurium . Devitalisation · Parasites

Responsible editor: Philippe Garrigues

Jan Venglovsky

jan@venglovsky.com

1 University of Veterinary Medicine and Pharmacy in Kosice, Komenského 73, 04181 Košice, Slovakia

2 Institute of Parasitology of the Slovak Academy of Sciences, Hlinkova 3, 04001 Košice, Slovakia

\section{Introduction}

Microbiological and parasitical risks related to application of pig slurry to soil

Pig slurry is classified as a natural fertiliser of animal origin, being a mixture of faeces, urine, remains of fodder and water used for the elimination of faeces. It is generated in litterless housing systems, where animals are kept on slatted or partially slatted floors. In the aspect of chemical composition, slurry is not a uniform material.

Chemical composition varies as it depends on many factors, such as the type and the age of animals, their feeding system and maintenance, the quality of fodder, as well as the dilution of the slurry and its storage method (Marszalek et al. 2014).

There are considerable variations microbiological compositions. Slurry is characterised by a high level of bacterial population; it can contain saprophytic microorganisms, pathogenic bacteria, viruses and fungi, as well as eggs and oocysts of gastro-intestinal parasites (Cotta et al. 2003). In slurry, there can be micro-organisms excreted by animals together with faeces, urine, milk, blood, purulent discharges, nasal and throat discharges, as well as discharges from vaginal tracts and amniotic fluid (Marszalek et al. 2014).

Animal manure is applied to soil with the aim to supply important nutrients to plants and to improve the soil structure. However, land-applied manure can represent a major reservoir of micro-organisms distributed across the landscape and available for loss to surface and ground water resources. While manure application can be managed to prevent much of the potential loss of pathogens and indicators (e.g., by managing application rates and forms, incorporation into the soil and use of buffers and setbacks between fields and waterways), poorly 
managed manure applications (e.g., application at excessive rates, onto saturated or frozen soils or without soil incorporation) can result in significant pathogen and indicator losses to surface and ground water.

When applying animal wastes to soil, we are concerned from the microbiological point of view with the presence of representatives of the family Enterobacteriacea, the majority of which have zoonotic character (such as Salmonella sp., Escherichia coli) and other germs (Mycobacterium sp., Enterococcus sp., Streptococcus sp., Staphylococcus sp.), which can be a threat to both farm animals and man.

Pathogens can survive or even grow in manure as this substrate provides the necessary nutrients and protects them against UV radiation, desiccation, and elevated temperature. On the other hand, there are several factors which support their die-off, such as predation, competition and inorganic ammonia. Temperature in particular is a critical factor in pathogen survival, with cooler temperatures generally enabling longer survival times. Bacterial pathogens such as Salmonella and E. coli $\mathrm{O} 157: \mathrm{H} 7$ can survive for several months in manure when environmental conditions are favourable (low temperatures, good moisture level). Increased temperatures, on the other hand, hasten die-off. The extent of this effect varies by organism, but survival in manure generally drops markedly at temperatures exceeding 20 to $30{ }^{\circ} \mathrm{C}$ compared with survival at cool temperatures $\left(1\right.$ to $9{ }^{\circ} \mathrm{C}$ ) (Rogers and Haines 2005).

This dependence of survival times on temperature results in seasonal trends; for example, a study of Salmonella typhimurium in swine slurry showed survival times of 26 days during summer and 85 days during winter (Venglovsky et al. 2006).

Most pathogenic bacteria are present in the environment only sporadically, at very low levels, and are difficult and expensive to detect directly. This is the reason why monitoring of risks was frequently based on determination of presence of more numerous and easier to monitor indicators of faecal contamination, such as faecal coliforms, E. coli and enterococci. Clostridium perfringens and coliphages can also be used as prospective indicators due to their presence in manure from all animals (Perdek et al. 2003).

Another group that was frequently used as an indicator of recent faecal contamination were faecal enterococci, a group of species of the genus Eterococcus, such as E. faecalis, E. faecium, E. avium, E. bovis, E. gallinarum and Str. equinus.

However, Ottoson et al. (2013) were evaluated enterococci as indicators for Salmonella but significantly slower decay rate and different behaviour in the material made them unsuitable as indicators for Salmonella in manure disinfected by ammonia or urea. According to Reissbrodt et al. (2000) they can persist in the environment, e.g., in soil, water or sewage, depending on the long-term survival of heavily stressed cells, particularly the so-called viable-but-nonculturable (VNC) organisms that have limited ability to grow on conventional laboratory plating media but are capable of reviving under in vivo conditions and causing diseases (Brandl 2006).

Côté and Quessy (2005) analysed samples of liquid hog manure, soil and vegetable (washed and unwashed) for the presence of Salmonella and E. coli. After application of manure to soil, E. coli counts decreased exponentially in the surface layer $(20 \mathrm{~cm})$. The estimated average time required to reach undetectable concentrations of $E$. coli in sandy loam varied from 56 to 70 days, while in loamy sand, E. coli could not be recovered after 77 days. The maximal Salmonella persistence in soil was 54 days. E. coli and Salmonella were not detected in any vegetable samples.

Stocker et al. (2015) investigated depth-dependent survival of $E$. coli and enterococci in soil after manure application and simulated rainfall. E. coli concentrations initially increased and then slowly decreased, whereas populations of enterococci began to decrease from the start and were not detectable after 4 weeks in all cases, except for treatments that received the least intense rainfall application.

Holley et al. (2006) added a six-strain cocktail of Salmonella serovars (Agona, Hadar, Heidelberg, Montevideo, Oranienburg, and Typhimurium) to about $5 \mathrm{~kg}$ of two soils (to yield $5 \log \mathrm{CFU} / \mathrm{g}$ ) with different moisture content (60 ad or $80 \%$ of field capacity) and to fresh pig slurry which was latter added to two soils at $25 \mathrm{~g} / \mathrm{kg}$ (to yield $5 \mathrm{log}$ CFU/g Salmonella). Storage of these soil treatments for 180 days at temperature sequences representing winter to summer, spring to summer, summer to winter seasonal periods, with four different temperature step lasting 45 days. Results showed that the largest decreases occurred within the first week. Higher moisture of soil, addition of manure and clay soil increased Salmonella survival. All but one of the treatments indicated that a 30-day delay between the field application of manure in the spring or autumn and use of the land for growing crop would ensure reasonable minimization of crop and animal contamination by Salmonella.

It is now commonly accepted that fruit and vegetables can be involved in spreading of enteric infections. Recently reported outbreaks related to fresh products included cases of Escherichia coli O157:H7 (spinach, lettuce), Salmonella typhimurium and S. newport (tomatoes, lettuce), $S$. thompson (rocket) and hepatitis A (spring onion). Consumption of fresh vegetable products, for example, lettuce, spinach and tomatoes, are commonly considered a potential risk factor for infection with enteropathogens such as Salmonella and Escherichia coli O157. Routes of spreading of these pathogens include application of animal manure as fertiliser, irrigation with water contaminated with faeces, direct contamination by livestock, wild animals and birds and postharvest contamination related to processing and worker hygiene. At present, postharvest interventions play the most important role in limiting the number of enteropathogens 
present on fresh products. The effectiveness of sanitizers is an important factor but their use in organic production is limited, thus prevention of contamination should be a preferred strategy (Heaton and Jones 2008).

The persistence of pathogens in environmental media depends on environmental conditions and the survival characteristics of the microbes present. The most important factors affecting survival of pathogens include temperature, ultraviolet (UV) radiation, moisture, $\mathrm{pH}$, availability of nutrients and competition for them concentration of ammonia in the medium and predation (Rogers and Haines 2005).

In soils, pathogen survival is influenced by temperature, moisture content, $\mathrm{pH}$, predation, nutrient availability, competition with native soil microorganisms and organic matter content. Aside from temperature, moisture exerts an important control, with increased moisture promoting survival. Faecal coliform bacteria survive longer in organic soils than in mineral soils, possibly due to the greater capacity of organic soils to hold water (EPA-OW, 2013).

Excrements of farm animals are also a source of endoparasites (cysts, eggs, larvae of genera Ascaris sp., Oesophagostomum sp., Trichuris sp., Strongyloides sp., Isospora sp., Eimeria sp., Giardia sp., Balantidium sp. and others) that may cause massive parasitic infections in both specific hosts and non-specific ones, such as human. An important factor in spreading of endoparasitoses is high tenacity of some propagative stages of parasites (Papajova and Juris 2012). The parasitic propagative stages, mainly endoparasitic protozoa and helminths, develop mostly outside their host's organism (Papajova and Juris, 2009). Ascaris suum eggs are hygienically the most problematic ones (Papajova and Juris, 2012). They are amongst the helminth eggs most resistant to environmental factors. They may survive in the nature for many years; therefore, they tend to accumulate in the environment (soil, water) (Crompton, 2001; Papajova and Juris, 2009; Olszewska et al., 2014).

A. suum infects pigs and besides, health consequences affects significantly economy of pig production due to production losses related to reduce efficiency of feed conversion and condemnation of "milk-spot" livers (Dubinský et al., 2000). The main route of A. suum eggs transmission is the transport and application of contaminated pig slurry directly to agricultural land or use of this slurry for spray irrigation after its previous dilution (Crompton, 2001; Venglovský et al., 2006; Olszewska et al., 2014).

\section{Materials and methods}

Raw pig slurry obtained from a pig farm was used in the experiment. The slurry was stored for 115 days in closed plastic containers of volume 51 as follows: (1) in a refrigerator at $4{ }^{\circ} \mathrm{C}$; (2) in a thermostat at $20^{\circ} \mathrm{C}$; (3) in a thermostat at $42{ }^{\circ} \mathrm{C}$. Examination was carried out in triplicate.
Before storage, lyophilised strain S. typhimurium SK 14/39 (SZÚ Prague, CR) was inoculated into the investigated slurry (initial count of $S$. typhimurium $3.6 \times 10^{9} \mathrm{CFU} . \mathrm{ml}^{-1}$ ).

Plate counts of total coliforms and E. coli $(\mathrm{CFU} / \mathrm{ml})$ were determined on Endo agar (HiMedia, India) with incubation at 37 or $43{ }^{\circ} \mathrm{C}$ for $24 \mathrm{~h}$, respectively.

Plate counts of faecal enterococci $(\mathrm{CFU} / \mathrm{ml})$ were determined on solid selective medium containing sodium azide (to suppress growth of Gram-negative bacteria) and colourless 2,3,5-trifenyltetrazolium chloride which is reduced by intestinal enterococci to red formazan. Typical colonies are convex, red, chestnut-brown or pink in colour either in the centre or throughout the colony surface.

Also, special polyurethane containers, each containing 1500 A. suum eggs, obtained by dissection of distal ends of the uterus of $A$. suum females, were introduced into the slurry.

Plate counts of tested bacterias $(\mathrm{CFU} / \mathrm{ml})$ were determined at days $0,7,12,22,32,40,55,90$ and 115 of storage. At the same intervals, devitalisation of A.suum eggs was observed in comparison with A.suum eggs stored in distilled water at the same temperatures.

The relevant physical and chemical properties were determined in homogenised slurry as follows: $\mathrm{pH}$ was determined by direct measurement with a glass electrode $\mathrm{pH}$ meter (HACH); dry mater (DM) was analysed by drying samples at $105{ }^{\circ} \mathrm{C}$ to a constant weight; ammonium ions $\left(\mathrm{NH}_{4}{ }^{+}\right)$were analysed by steam distillation and titration.

The count of selected micro-organisms was expressed as mean of $\log _{10}$ CFU. $\mathrm{ml}^{-1} \pm$ standard deviation. Significance of differences between experimental and control groups was determined using Student's $t$ test and ANOVA test at the levels of significance 0.05, 0.01 and 0.001 (Statistica 6.0).

The number of viable $A$. suum eggs was expressed as mean \pm standard deviation. Significance of differences between experimental and control groups of parasites was determined using Student's $t$ test, ANOVA and Dunnet Multiple Comparison test at the levels of significance 0.05, 0.01 and 0.001 (Statistica 6.0).

The methods of regression analysis (least squares methods and the robust regression method) were used for the correlation between changes of physico-chemical parameters of stored slurry and survival of model organisms (bacteria and parasites).

\section{Results and discussion}

Reduction of enteric pathogens in animal manures before field application is essential for mitigating the risk of foodborne illness associated with produce. The aim of the study was to investigate the viability of $S$. typhimurium, E. coli, total coliforms, faecal enterococci and A. suum eggs in raw pig slurry stored at different temperatures in order to assess the microbial and parasitic risks related to application of animal wastes to soil. 
Fig. 1 Survival of S. typhimurium at different temperatures expressed as $\log 10 \mathrm{CFU} \mathrm{ml} \mathrm{m}^{-1}$

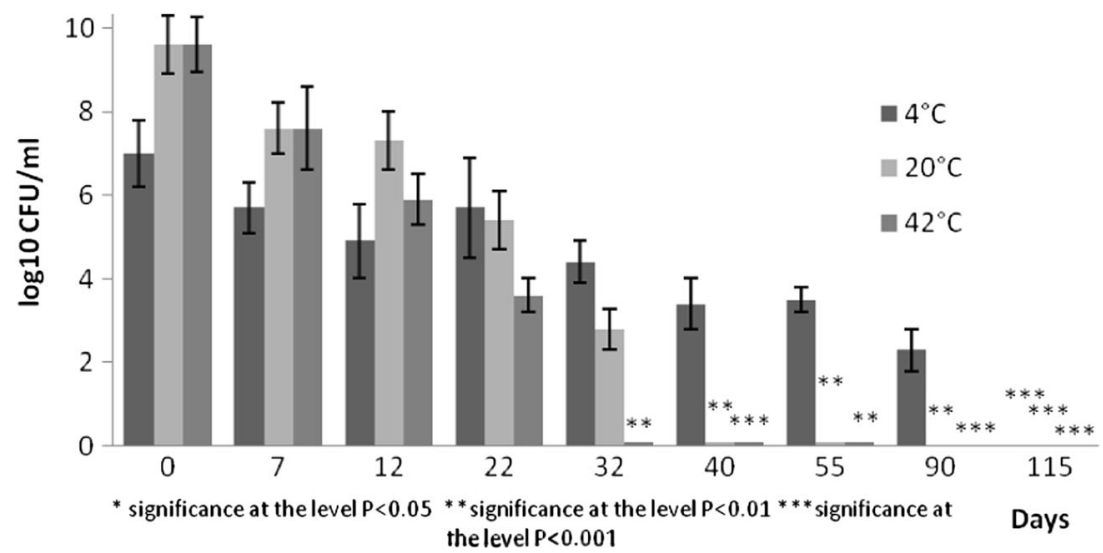

The plate counts of investigated micro-organisms in slurry stored at different temperatures are illustrated in Figs. 1, 2, 3 and 4. The initial concentration of the tested S. typhimurium strain in manure stored at $4{ }^{\circ} \mathrm{C}$ decreased by three orders of magnitude by day 90 , and by day 115 , the test strain was not recovered. Storage at $20{ }^{\circ} \mathrm{C}$ resulted in a marked decrease by seven orders of magnitude by day 32 , and after this day, the test strain was detected only qualitatively. The most pronounced reduction in plate counts of $S$. typhimurium $(P<0.01)$ was observed after storage at $42{ }^{\circ} \mathrm{C}$ after 32 days exposure (Fig. 1).

Indicator bacteria represented by $E$. coli decreased by two orders at $4{ }^{\circ} \mathrm{C}$ and six orders at $20^{\circ} \mathrm{C}$ by the day 115 . Their counts decreased by six orders by the day 90 at $42{ }^{\circ} \mathrm{C}$ (Fig. 2). Abatement of total coliforms was by two orders $\left(4^{\circ} \mathrm{C}\right)$ and by four orders $\left(20^{\circ} \mathrm{C}, 42^{\circ} \mathrm{C}\right)$. Similar decrease was observed for faecal enterococci decreased by two to three orders. The most marked decrease by six orders in plate counts of faecal enterococci was recorded in pig slurry stored at $42{ }^{\circ} \mathrm{C}$ in 115 days.

The effect of long-term storage (up to 185 days) of slurry on the survival of some indicator microorganisms was investigated under practical conditions. Whereas, the total bacterial counts as well as the numbers of Enterobacteriaceae, E.coli and faecal enterococci remained members of colony forming units of Salmonella exposed to the slurry by a special germ carrier technique including semipermeable membranes were reduced by more than five $\log 10$. Yersinia colitica was completely inactivated within only a few days, whereas the eggs of Ascaris suum lost their viability very slowly (Rapp, 1995).

Howell et al. (1996) observed that faecal coliforms experienced greater growth under warm conditions than faecal enterococcus. The authors of this study observed frequent regrowth of faecal coliforms but not of faecal enterococci.

Although survival of Salmonella in soil for more than 900 days was known earlier, its pathogenicity for roots and other plant parts remained questionable.

Incorporating wastes into the soil by tillage may enhance survival of micro-organisms because they are sheltered from lethal stresses, but incorporation also removes microorganisms from interaction with surface runoff and places faecal microorganisms in an environment where predation by soil organisms can further reduce their numbers. Liquid manure-applied pasture is deposited on vegetation, where desiccation, high temperatures, and sunlight will devitalize majority of micro-organisms. However, faecal bacteria appear to survive for long periods (e.g., > 100 days) in cowpies, where they are relatively protected from the environmental factors and can eventually pass to soil. In the soil, micro-organisms are effectively removed from the percolating water by adsorption, filtration and predation (EPA-OW 2013).
Fig. 2 Survival of Total coliforms at different temperatures expressed as $\log 10 \mathrm{CFU} \mathrm{ml} \mathrm{m}^{-1}$

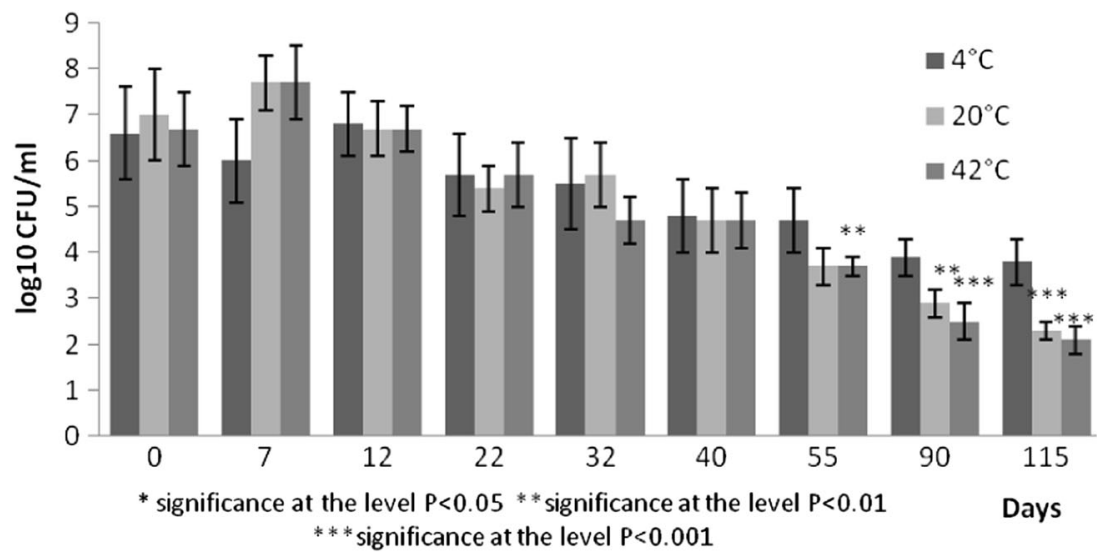


Fig. 3 Survival of E.coli at different temperatures expressed as $\log 10 \mathrm{CFU} / \mathrm{ml}$

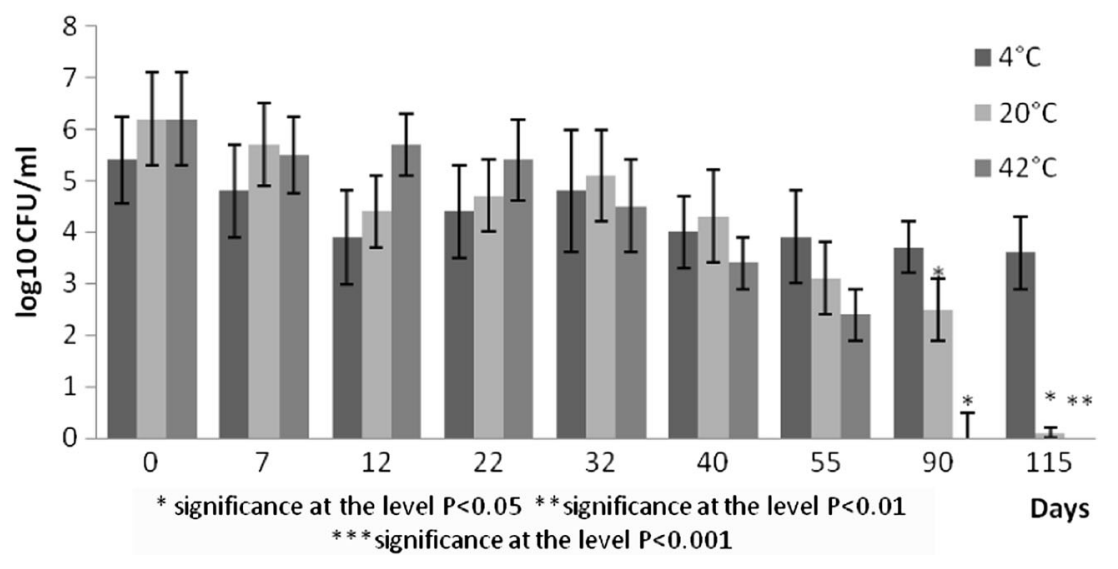

Manure management methods should consider the different survival capabilities of the various pathogens and relevant properties of the manure that may affect their devitalisation. There are many unanswered questions in this area that warrant further research. Timing of manure land application is an important factor in minimising pathogen transport via runoff. Transport of microorganisms in runoff is more likely if excess manure is applied or if manure is misapplied (USEPA 2002).

Arrus et al. (2006) investigated the influence of temperature on survival of $S$. typhimurium and observed that did not grow in hog manure. However, storage reservoir temperatures facilitated salmonella survival during winter which contributed to the risk of contamination of fields at spring application (Reissbrodt et al. 2000).

Besides temperature and time of storage, the survival of pathogens in the slurry may well depend on factors other than temperature and duration of heat treatment, e.g., moisture content, free ammonia concentration, $\mathrm{pH}$, the presence of other micro-organisms and other physico-chemical properties (Venglovský et al. 2006). This was the reason why the stored pig slurry was subjected also to physico-chemical examination.

The initial DM content gradually decreased throughout the experiment from the $28.00 \pm 6.26 \mathrm{~g} \mathrm{~kg}^{-1}$ to $15.09 \pm 1.23$ at $4{ }^{\circ} \mathrm{C}, 13.09 \pm 4.12$ at $20{ }^{\circ} \mathrm{C}$ and $12.89 \pm 1.05 \mathrm{~g} \mathrm{~kg}^{-1} \mathrm{DM}$ at $42{ }^{\circ} \mathrm{C}$. This decrease was most likely related to the release of some volatile compounds from slurry as a result of decomposition processes taking place during its storage. The changes in $\mathrm{pH}$ and ammonia level in pig slurry stored at different temperatures are illustrated in Fig. 5.

With some fluctuations, the $\mathrm{pH}$ level increased throughout the storage at all three temperatures from the initial $6.95 \pm 0.11$ to $8.35 \pm 0.58$ at $4{ }^{\circ} \mathrm{C}$, to $8.55 \pm 0.17$ at $20{ }^{\circ} \mathrm{C}$ and to $9.35 \pm 0.05$ at $42{ }^{\circ} \mathrm{C}$. While at 4 and $20^{\circ} \mathrm{C}$, it took 90 and 55 days, resp. to reach the level of 8.00 ; at $42^{\circ} \mathrm{C}$, this level was reached already after 12 days. The initial level of $\mathrm{NH}_{4}{ }^{+}$in the slurry was $50.00 \pm 21.11 \mathrm{~g} \mathrm{~kg}^{-1} \mathrm{DM}$; it fluctuated considerably during the experiment, and the final level of this parameter differed between the treatments. At $4{ }^{\circ} \mathrm{C}$, it peaked at day 40 (295.5 $\mathrm{g} \mathrm{kg}^{-1} \mathrm{DM}$ ) and then decreased to $84.13 \pm 21.23 \mathrm{~g} \mathrm{~kg}^{-1}$ DM. At $20{ }^{\circ} \mathrm{C}$, there were two peaks at days 12 and 32 $\left(200.45 \pm 50.83\right.$ and $\left.225.45 \pm 54.23 \mathrm{~g} \mathrm{~kg}^{-1} \mathrm{DM}\right)$ and the final concentration was $27.11 \pm 1.06 \mathrm{~g} \mathrm{~kg}^{-1} \mathrm{DM}$. These two peaks coincided with a slight increase in $\mathrm{pH}$. At $42^{\circ} \mathrm{C}$, there was one distinct peak at day $32\left(215.13 \pm 14.12 \mathrm{~g} \mathrm{~kg}^{-1} \mathrm{DM}\right)$ after which the concentration of this parameter decreased abruptly and at day 115 , we recorded only $0.56 \pm 0.01 \mathrm{~g} \mathrm{~kg}^{-1} \mathrm{DM}$. The peak at day 32 was again reflected in increased $\mathrm{pH}$ level. The peaks were most likely related to decomposition of nitrogenous substances in the slurry and the final decreased levels to volatilisation in the form of $\mathrm{NH}_{3}$ at $\mathrm{pH}$ above.

Correlation and regression analysis confirmed significant relationship only between the number of micro-organisms in
Fig. 4 Survival of Faecal enterococci at different temperatures expressed as $\log 10$ $\mathrm{CFU} / \mathrm{ml}$

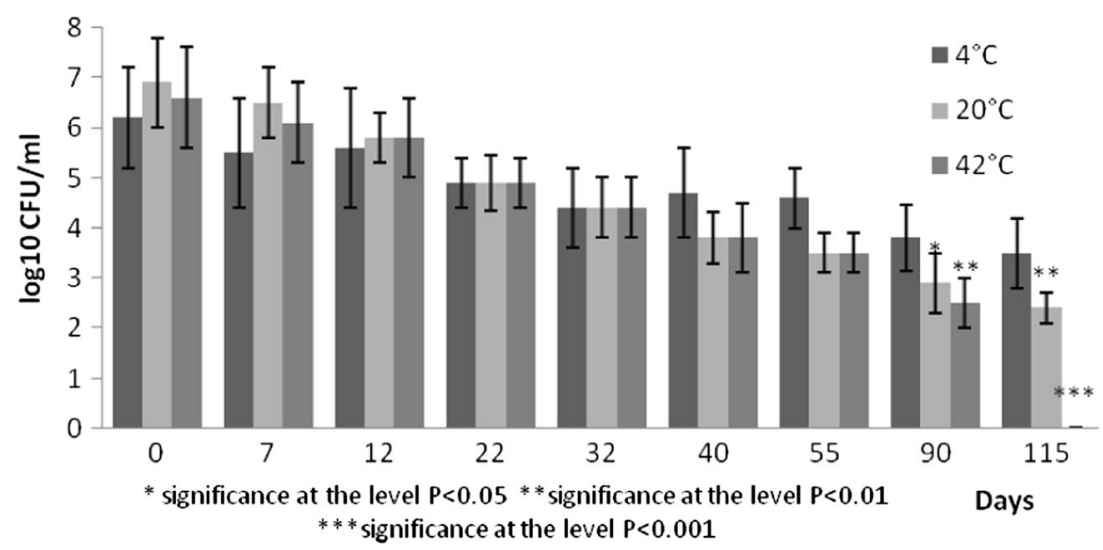


Fig. 5 The course of $\mathrm{pH}$ and ammonium concentrations in slurry at different temperature

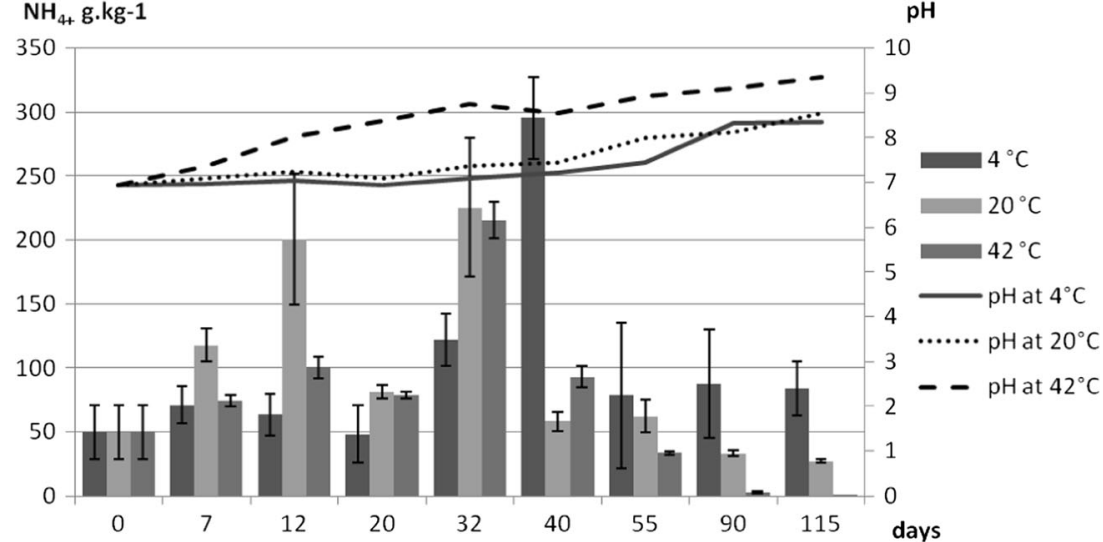

the slurry and $\mathrm{pH}$. Relationship between devitalization of investigated micro-organisms and the ammonium content in the slurry was not detected.

However, the initial content of ammonia in fresh slurry (DM content approx. $2.8 \%$ ) reached only $0.14 \%$ and at the highest peak, it increased for short time to about $0.3-0.4 \%$ at the maximum (depending on DM), which was probably not high enough to exert some influence on devitalization of micro-organisms.

It is generally known that some eggs, infectious larvae (L3), oocysts or sporocysts can survive for considerable time in the environment, frequently for several years, even under unfavourable conditions. The main subject of concern is highly resistant eggs of some parasitic nematodes such as Ascaris spp., Trichuris spp. and coccidial oocysts (Juris et al. 2000).

Parasite survival in animal manures may also be related to temperature, but the trends are not as pronounced as those reported for bacterial pathogens. This is likely due to their ability to form cysts and oocysts for protection from environmental pressures. According to Olson (2001), A. suum eggs are highly resistant to inactivation in faeces where they may remain infectious for years. A direct contact with infected animal and its faeces, contaminated environment or food chain (water, vegetables) are considered potential risk factors (Papajova and Juris 2012).

Roesel et al. (2017) observed prevalence of gastrointestinal parasites in pigs reared on small farms in Uganda. Altogether, they examined 932 pigs and detected developmental stages of endoparasites in $61.4 \%$ of examined animals. In the faeces of pigs, they found most frequently Strongylid eggs $(57.1 \%)$ and eggs of Metastrongylus spp. (7.6\%), Ascaris suum (5.9\%), Strongyloides ransomi (4.2\%) and Trichuris suis (3.4\%). Coccidial oocysts were found in $40.7 \%$ of the examined animals.

Our study showed that higher temperatures supported devitalisation of A.suum eggs (Fig. 6).

Results of statistical analysis (the least square methods and the robust regression method) indicated that the devitalisation of model organisms was most affected by temperature and $\mathrm{pH}$. There was a quadratic relationship between the number of devitalised eggs and temperature while the relationship between the number of eggs and $\mathrm{pH}$ was linear. The effect of $\mathrm{NH} 4+$ concentration was insignificant.

Besides temperature and the time of storage, the survival of pathogens in the slurry may well depend on factors other than temperature and duration of heat treatment, e.g., moisture
Fig. 6 Viable Ascaris suum eggs in raw pig slurry

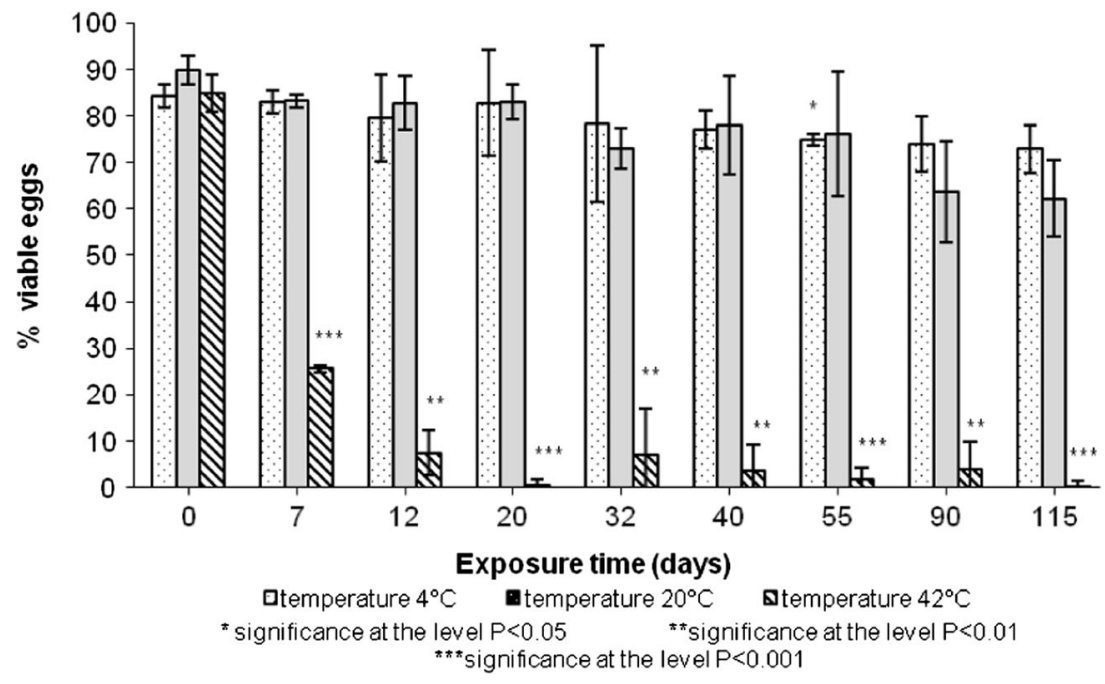


content, free ammonia concentration, $\mathrm{pH}$, the presence of other micro-organisms and other physico-chemical properties (Venglovsky et al. 2006).

For this reason, the stored pig slurry was subjected also to physico-chemical examination. Changes in physico-chemical parameters were related to decomposition processes; however, some variations were observed which require further study.

\section{Conclusions}

There are significant microbiological risks related to animal wastes spread onto land used for crop production or livestock grazing. Animal slurries are of particular concern, as the temperature in these substrates during their storage and some ways of common processing does not ensure complete devitalisation of potential bacterial and viral pathogens and eggs of parasites, as indicated by our observation of devitalisation of S. typhimurium, E. coli, total coliforms, faecal enterococci and $A$. suum eggs at 4,20 and $42{ }^{\circ} \mathrm{C}$ during 115 days of storage.

In advanced countries, relevant legislative regulations require acceptable procedures for the disposal, processing and application of animal manures. However, there are still aspects that may raise some risk for safety of human food chain and require further investigations.

The best way is to put stress on preventive actions and measures that may eliminate any known or suspected danger resulting from pathogens present in animal manures applied to the soil that is used for animal grazing or growing of crops for human consumption.

Funding information The study was supported by Ministry of Culture and Education Grant Agency No. 003UVLF-4/2016 (0.2) and by the project VEGA 2/0125/17 (0.8).

Open Access This article is distributed under the terms of the Creative Commons Attribution 4.0 International License (http:// creativecommons.org/licenses/by/4.0/), which permits unrestricted use, distribution, and reproduction in any medium, provided you give appropriate credit to the original author(s) and the source, provide a link to the Creative Commons license, and indicate if changes were made.

\section{References}

Arrus KM, Holley RA, Ominski KH, Tenuta M, Blank G (2006) Influence of temperature on Salmonella survival in hog manure slurry and seasonal temperature profiles in farm manure storage reservoirs. Livest Sci 102:226-236

Brandl MT (2006) Fitness of human enteric pathogens on plants and implications for food safety. Annu Rev Phytopathol 44:367-392

Côté C, Quessy S (2005) Persistence of Eschericia coli and Salmonella in surface soil following application of liquid hog manure for production of pickling cucumbers. J Food Prot 68(5):900-905.

application of liquid hog manure for production of pickling cucumbers. $\mathrm{J}$ Food Prot 68(5):900-905.
Cotta MA, Whitehead TR, Zeltwanger RL (2003) Isolation, characterization and comparison of bacteria from swine faeces and manure storage pits. Environ Microbiol 5(9):737-745

Crompton DW (2001) Ascaris and ascariasis. Adv Parasitol 48:285-375

Dubinský P, Krupicer I, Levkut M, Švický E, Dvorožňáková E, Revajová V, Vasilková Z, Kováč G, Reiterová K, Lenhardt L, Ondrejka R, Papajová I, Moncol DJ (2000) Influence of Ascaris suum infection on ruminants. In: Dubinský P, Juriš P, Moncol DJ (eds) Environmental protection against the spread of pathogenic agents of diseases through the wastes of animal production in the Slovak Republic. Harlequine, Ltd., Kosice, pp 143-160

EPA-OW (2013) Literature review of contaminants in livestock and poultry manure and implications for water quality. United States Environmental Protection Agency, Office of Water (4304 T) EPA 820-R-13-002

Heaton JC, Jones K (2008) Microbial contamination of fruit and vegetables and the behaviour of enteropathogens in the phyllosphere: a review. J Appl Microbiol 104(3):613-626

Holley RA, Arrus KM, Ominski KH, Tenuta M, Blank G (2006) Salmonella survival in manure-treated soils during simulated seasonal temperature exposure. J Environ Qual 35(4):1170-1180

Howell JM, Coyne MS, Cornelius PL (1996) Effect of sediment particle size and temperature on fecal bacteria mortality rates and the fecal coliform/fecal streptococci ratio. J Environ Qual 25:1216-1220

Juris P, Rataj D, Ondrasovic M, Sokol J, Novak P (2000) Sanitary and ecological requirements on recycling of organic wastes in agriculture. Vasko Press, Presov, p 178 (in Slovak)

Marszalek M, Kowalski Z, Makara A (2014) Physicochemical and microbiological characteristics of pig slurry. Tech Trans Chem 1:81-91

National Conference, Winnipeg, Manitoba, Canada, Agriculture and Agri-Food Canada

Olson M E (2001) Human and animal pathogens in manure. In Livestock Options for the FutureNational Conference, Winnipeg, Manitoba, Canada, Agriculture and Agri-Food Canada

Olszewska H, Skowron K, Skowron KJ, Kaczmarek A (2014) The reduction rate of invasive Ascaris suum eggs number in slurry and humus layers of selected soil types. Helminthologia 51(3):203-209

Ottoson J, Nordin A, von Rosen D, Vinnerås B (2013) Salmonella reduction in manure by the addition of urea and ammonia. Bioresour Technol 99(6):1610-1615

Papajova I, Juris P (2009) The effect of composting on the survival of parasitic germs. In: Pereira JC, Bolin JL (eds) Composting: processing, materials and approaches. Nova Science Publishers, New York, pp 113-154

Papajova I, Juris P (2012) The sanitation of animal waste using anaerobic stabilisation. In: Kumar S, Bharti A (eds) Management of organic waste. InTech, 49-68

Perdek J, Arnone R, Stinson M (2003) Managing urban watershed pathogen contamination. Rep. EPA/600/R-03/111. U.S. Environ. Protect. Agency, Cincinnati

Rapp A (1995) Hygienisch- mikrobiologische Untersuchungen zum Verhalten von asgewählten Bakterien und Viren während der längerfristigen Speicherung von Flüssigmist in Güllegemeinschaftsanlagen. Dissertation an der Uni Hohenheim

Reissbrodt R, Heier H, Tschäpe H, Kingsley RA, Williams PH (2000) Resuscitation by ferrioxamine E of stressed Salmonella enterica serovar typhimurium from soil and water microcosms. Appl Environ Microbiol 66(9):4128-4130

Roesel K, Dohoo I, Baumann M, Dione M, Grace D, Clausen PH (2017) Prevalence and risk factors for gastrointestinal parasites in smallscale pig enterprises in Central and Eastern Uganda. Parasitol Res 116(1):335-345

Rogers S, Haines J (2005) Detecting and mitigating the environmental impact of fecal pathogens originating from confined animal feeding operations: review. EPA-600-R-06-021. USEPA, Office of Research 
and Development, National Risk Management Research Laboratory, Cincinnati

Stocker MD, Pachepsky YA, Hill RL, Shelton DR (2015) Depthdependent survival of Escherichia coli and enterococci in soil after manure application and simulated rainfall. Appl Environ Microbiol 81(14):4801-4808
USEPA (2002) Environmental and economic benefit analysis of final revisions to the national pollutant discharge elimination system regulation and the effluent guidelines for concentrated animal feeding operations. EPA-821-R-03-003

Venglovsky J, Martinez J, Placha I (2006) Hygienic and ecological risks connected with utilization of animal manures and biosolids in agriculture. Livest Sci 102(3):197-203 